\title{
Antimicrobial, antioxidant, phytochemical and pharmacognostic study of the leaf powder of Ficus carica $\mathbf{L}$.
}

\author{
Hussan Ara Begum ${ }^{1 *}$, Muhammad Hamayun ${ }^{1}$, Mamoona Rauf ${ }^{1}$, \\ Humaira Gul ${ }^{1}$, Kishwar $\mathrm{Ali}^{2}$, Waqar Khan ${ }^{2}$, Mark Schulze ${ }^{3}$ and Mohib \\ Shah $^{1}$
}

1. Department of Botany, Abdul Wali Khan University Mardan-Pakistan

2. Department of Botany, University of Malakand, Dir (L) KP-Pakistan

3. Department of Education, University of South Africa (UNISA)-South Africa

*Corresponding author's email: hussanara.begum@gmail.com

Citation

Hussan Ara Begum, Muhammad Hamayun, Mamoona Rauf, Humaira Gul, Kishwar Ali, Waqar Khan, Mark Schulze and Mohib Shah. Antimicrobial, antioxidant, phytochemical and pharmacognostic study of the leaf powder of Ficus carica L. Pure and Applied Biology. Vol. 9, Issue 1, pp999-1008.

http://dx.doi.org/10.19045/bspab.2020.90105

Received: 04/09/2019 Revised: 01/12/2019

Accepted: 02/01/2020

Online First: 18/01/2020

\section{Abstract}

Ficus carica L., (Moraceae), commonly found in tropical and subtropical areas, known for its ethnomedicinal uses. The current work aimed to study macro and microscopic features and screen the plant ethanol extract for its antioxidant and antimicrobial potential. 1, 1-diphenyl-2-picryl hydrazyl (DPPH) was used for antioxidant and Agar-well-diffusion method for screening antimicrobial activity. The results revealed that powdered drug possess unicellular, uniserrate covering trichomes, parenchymatous tissue containing spiral vascular strands, anomocytic stomata and calcium oxalate crystals. Phytochemically, the extract possesses reducing sugars, polysaccharides, oxalic acid, amino acid and proteins. The antioxidant activity of Ficus carica leaves ethanol extract, using various concentration $(125,250,500,750$ and $1000 \mu \mathrm{g} / \mathrm{ml})$ gave the results of $21.42 \pm 01,29.65 \pm 03,53.15 \pm 03$, $57.00 \pm 01$ and $62.99 \pm 05$, respectively. The leaves ethanol extract used for antibacterial activity have concentrations of 200 and $500 \mathrm{mg} / \mathrm{ml}$, both of which were found effective against the selected bacterial strains. K. pneumonia was inhibited (18 \& 28mm), E. coli was found ( $20 \& 26 \mathrm{~mm}$ ) susceptible, Staphylococcus aureus was inhibited with (24 and $26 \mathrm{~mm})$ and Pseudomonas aeruginosa was inhibited by (22 and $28 \mathrm{~mm})$. It is concluded from the present study that leaf ethanol extract of Ficus carica has good antioxidant constituents and possess positive antimicrobial chemical metabolites. These metabolites can be used to treat various infectious and chronic diseases caused by microbes. This work is important in order to assess the significance of Ficus carica used locally. More research is required to isolate these metabolites to establish clinical trials for human benefits.

Keywords: Antimicrobial; Antioxidant; Ficus Carica; Medicinal Plants; Phytochemicals

Introduction
Plants are recognized as the primary source in traditional care systems due to their curative potency. Likewise, Ficus carica L., a member of the mulberry tree family (Moraceae) is medicinally important and the oldest known fruit tree to humans [1]. Ficus carica is known with various names in 
different languages, e.g. (Anjir-Urdu), (figs English), (teen-Arabic), collective (fig-tree), (Hindi-angir), (Sansikrit-angira), (PashtoInzir), (Punjabi-fagar) [2, 3].

Ficus has been used as a common medicinal plant for various ailments. Ficus sap has been used in many intoxicants of superstitions by Peruvian Shamans [4]. The Genus Ficus comprises more than 800 species of the family Moraceae. Several Ficus types comprise of several selections, vital in genetic variety and outstanding biological actions [5]. It is believed that the plant has been imported from western Asia to the Mediterranean. The plant is predominantly cultivated as a cash crop in characteristically slightly cold weather with dry hot season in countries like USA, Brazil, Turkey, and some Middle Eastern countries [6].

Ficus carica is globally cultivated for its edible fruits. Its fruits can be consumed fresh, dehydrated, preserved, or in other conserved forms. Ficus is one among the therapeutic vegetation principally arising in sub-tropical and tropical areas around the globe [7]. Various parts of the plant like wood, green leaves, soft branches, berries and sap are used for therapeutic and medicinal purposes. The fruit of the plant is nutritious and is of high commercial value. Vitamins, minerals, calcium, fibres, fats and water are in abundance in the fruit. Conferring to United State Department for Agriculture (USDA) the Task Diversity, dehydrated fruits are rich in fibre, copper, manganese, magnesium, potassium, calcium and vitamin $\mathrm{K}$, absolute to man requirements, possess lesser quantities of several supplementary nutrients. The plant is cathartic and comprises various antioxidants, flavonoids and polyphenols [8]. Certain bioactive complexes such as arabinose, $\quad \beta$-amyrins, $\quad \beta$-carotenes, glycosides, B-sitosterol and xanthotoxol have been found in the plant $[9,10]$. The dehydrated fruits have a substantial rise in plasma antioxidant dimensions and used in many ailments like abdominal, breathing, provocative, cardiac problems, ulcers and cancers $[11,12]$. In curing leucodermis and ringworm diseases, root is used locally while fruits possess antipyretic, purgative, aphrodisiac characteristics and relieving in irritation [13]. Ficus carica has been described as a good antioxidant, effective antiviral, antibacterial, antidiabetic, beating cancer and anthelmintic $[14,15]$. Locally the plant is used in different illnesses like stomach problems, throat problems and normal tummy pain due to indigestion [16]. Research work has been done on dry and fresh fig fruit and leaves [17]. Various biological activities have been carried out on different parts of Ficus carica [18]. The current research aims at the antibacterial, antioxidant activities, phytochemical analysis and pharmacognostic examination of leaf powder of the medicinal plant Ficus carica.

\section{Distribution}

The Fig tree is widely dispersed, found in Asia to the Americas. Countries like Turkey and Spain are the key exporters of the fruit in Europe. Parts of the United States including California and other Western coastal states have plenty of commercial orchards of the plants. Arabia, Persia, India, China and Japan are exporter the plant to a moderate level. In India, Punjab and Uttar Pradesh are the bigger producers of the Fig fruits [19].

\section{Morphology}

The tree of Ficus carica L. is $15-20 \mathrm{ft}$. tall, with scattering branches and stalk of $7 \mathrm{ft}$. in diameter. Plants have creamy white latex which chiefly comprises of ficin (a protein digesting enzyme). The roots are typically shallow and spreading [20]. The leaves are wide, oval or lobbed, upper surface is coarse above and juvenile underneath. Fruit is axillary, different in mass and pigment. Ripened fruit is juicy and sugary, unripe fruit is gummy [21, 22]. Seeds are of different sizes and vary from 30 to 1600 in number in 
each fruit. The seeds are the real fruits in figs [23]. 26 are the normal diploid numbers of chromosome of different species are analogous to one another in appearance in all plants. The genome size of the fig is very small, less than three times that of Arabidopsis sp. [24, 25].

\section{Materials and methods}

\section{Plant material collection}

Experimental material was collected locally and identified with the help of available literature and experts at Abdul Wali Khan University Mardan. The leaves were separated from the plant stem, washed, cleaned and dried in an oven at $45^{\circ}$. After drying, the plant material (Leaves) was powdered for further use. Ethanol was added to the powdered material and kept for 3 days to get the plant extracts.

\section{Pharmacognostic Analysis}

The leaf morphology was studied under the microscope. The dried-out leaf powdered material was used for this purpose and the extracts were used for the determination of phytochemical constituents [26].

\section{Phytochemical tests}

Benedict's test for reducing sugars: To a clean and dry test tube containing $3 \mathrm{ml}$ of sample solution, 2-3 ml of Benedict's reagent was added and then boiled for 5 minutes.

\section{Iodine test for non-reducing sugars}

To about 2-3 $\mathrm{ml}$ of the sample solution, a couple of drops of iodine dye were added.

\section{Tannic acid test for polysaccharides}

About $60 \mathrm{ml}$ of $20 \%$ tannic acid was added to 3-4 ml of sample solution.

\section{Tests for Oxalic acid}

1) Calcium chloride test: To the sample solution, a few drops of 5\% Calcium chloride solution were added.

2) Lead acetate test: To the sample solution, a few drops of $5 \%$ Lead acetate solution were added.

Test for Amino acid

Test for cysteine: About 5ml of sample solution was boiled with a little of $40 \%$
$\mathrm{NaOH}$ and a few drops of $10 \%$ Lead acetate solution.

\section{Test for Proteins}

1) Biuret test: To about $3 \mathrm{ml}$ of sample solution, $1 \mathrm{ml}$ of $4 \% \mathrm{NaOH}$ solution and a few drops of $1 \%$ of Copper Sulphate $\left(\mathrm{CuSO}_{4}\right)$ solution were added.

2) Test for sulphur containing protein: About $5 \mathrm{ml}$ of sample solution was boiled after the addition of few millilitres of $40 \% \mathrm{NaOH}$ solution and a drop or two of $10 \%$ Lead acetate solution.

\section{Tests for Tannins}

1) A few drops of $5 \%$ Ferric chloride solution were added to the extracted solution.

2) A few drops of Acetic acid $\left(\mathrm{Ch}_{3} \mathrm{COOH}\right)$ were added to the extracted solution.

3) Potassium dichromate drops were added to the extracted solution.

Tests for Alkaloids

1) Mayer's test: To about $3 \mathrm{ml}$ of extract, a few drops of Mayer's reagent were added.

2) Wagner's test: To about $3 \mathrm{ml}$ of extract, a few drops of Wagner's reagent were added.

\section{Antioxidant activity}

1, 1-diphenyl-2-picryl hydrazyl (DPPH) free radical scavenging assay

To measure the free radical scavenging activity of the powdered leaf extract, we used 1, 1-diphenyl-2-picryl hydrazyl (DPPH) assay following the method of [27]. Ascorbic acid was used as a standard solution to compare with. A $0.1 \mathrm{~mm}$ concentration solution of DPPH in methanol was prepared by adding $1 \mathrm{ml}$ of this solution to $3 \mathrm{ml}$. of the crude extract in ethanol at a different concentration $(100,250,500,750 \& 1000$ $\mu \mathrm{g} / \mathrm{ml})$. The mixture was shaken vigorously and allowed to stand at room temperature for an hour; using a spectrophotometer, absorbance was measured at $517 \mathrm{~nm}$. The percent DPPH scavenging effect was considered by using the following calculations.

DPPH scavenging effect (\%) or Percent inhibition $=\mathrm{A}_{0}-\mathrm{A}_{1} / \mathrm{A}_{0} \times 100$. 
Where $\mathrm{A}_{0}$ was the Absorbance of control reaction and $A_{1}$ was the Absorbance in the presence of test or standard sample [28].

\section{Antibacterial activity}

\section{Bacterial strains}

Klebsella pnaumunae, Staphylococcus aureus, Pseudomonas aeruginosa and Escherichia coli bacteria were used for antibacterial activity to check the leaf ethanol extract.

\section{Preparation of inoculum}

Some selected bacterial strains from a 24hour old culture were mixed with physiological normal saline solution to get a McFarland turbidity standard $\left[10^{6}\right.$ colony forming unit (CFU) $\mathrm{ml}^{-1}$ ]. The LB Ager medium was then inoculated with the prepared bacterial samples. Preparation of Agar plates followed the agar well diffusion method [29].

\section{Concentration of extract for activity}

Two concentrations were used for activity $1 \mathrm{mg} / 1 \mathrm{ml}$ and $5 \mathrm{mg} / 1 \mathrm{ml}$ dissolved in DMSO. Solution of a standard antibiotic $(1 \mathrm{mg} / 1 \mathrm{ml}$ of Cefotaxime) were used as a positive and DMSO as negative controls.

Pouring of test solution, incubation and measurement of zone of inhibition

$75 \mu \mathrm{l}$ of test sample was poured into a labelled micropipette. At $37^{\circ} \mathrm{C}$, incubation was done for 24 hours and the diameter of clear zones were recorded and the bacterial growth around each well was measured. The average of inhibition zone and standard deviation was calculated from three trials.

\section{Results and discussion}

\section{Medicinal uses}

Common fig has laxative, calmative, cough relieving and analgesic properties. It is actively used in the research of making laxative syrups, along with Senna and other carminatives. A decoction of the fruit is second hand in case of chills, relaxing the mucous membranes of the respiratory tract. Fresh figs can be used superficially as an emollient and in dressings in the treatment of boils and small swellings. Sap taken out from stems and leaves is used for treating warts.

\section{Macroscopic Analysis}

Leaves were green, odourless with a slight bitter taste and fracture was horney. The leaves varied from 7-9 cm in length and 4-6 $\mathrm{cm}$ in width. The upper surface of the leaf is rough white while the lower one is rough and green. Other peculiar features include oval apex, cordate base, and serrate margins and reticulate venation in the leaves.

\section{Microscopic Analysis}

The transverse section of the leaf reveals a single layered epidermis and a thin and smooth cuticle. The stomata are anomocytic, trichomes are non-glandular (sometimes unicellular and uniserrate) with two layers of palisade parenchyma of mesophyll and four layers of spongy parenchyma where Calcium oxalate crystals are present. There is a biconvex midrib, angular cells of collenchyma in about 8-10 rows and the collateral vascular bundles are entrenched in the ground parenchyma.

\section{Powder analysis}

1. Trichomes were abundant and have pointed at the apexes and thick bases.

2. Parenchyma tissue with spiral vascular strands.

3. Anomocytic stomata are present.

4. 7-10 microns in diameter prismatic Calcium oxalate crystals found as free and in fragments of parenchymatous cells.

Ficus carica has simple leaves, large shape, acute tip and subcordate base, irregular deeply cut palmate leaf, irregular margin, measuring 6-18 cm long and 5-15 cm wide, petiolate, rough lamina texture and multiconvergent reticulate venation.

Behaviour of the crude powdered drug with chemical reagents

Behaviour of the crude powder obtained from leaf was analysed with different chemical reagents to detect the presence of Phytoconstituents. The results were analysed with 
the colour change under ordinary daylight (Table 1).

Table 1. Behaviour of the Ficus powder with chemical reagents

\begin{tabular}{|c|c|c|}
\hline Reagents & Color/ppt & Constituents \\
\hline $\mathrm{FeCl}_{3}$ & No color & Tannins absent \\
\hline Iodine & No color & Starch absent \\
\hline $\mathrm{KOH}$ & Yellow & Anthraquinone glycosides present \\
\hline $\mathrm{AgNO}_{3}$ & Ppt & Protein present \\
\hline $\mathrm{NaOH}$ & Yellow & Flavonoid present \\
\hline $\mathrm{H}_{2} \mathrm{SO}_{4}$ & Reddish brown & Steroids and terpenoids present \\
\hline
\end{tabular}

Colour reaction of the powder with different solvents and acids

Different solvents and acids react with the powdered material of the leaf of the plant with a peculiar colour (Table 2). The powdered material was treated with different solvents, reagents and acids which gave different colours corresponding to the presence of different constituents.

Table 2. Colour reactions of the Ficus powder with different solvents and acids

\begin{tabular}{|c|c|c|}
\hline S. No. & Acids & Color \\
\hline 01 & Phosphoric acid & Dark green \\
\hline 02 & $\mathrm{HCl}$ & Dark green \\
\hline 03 & $\mathrm{H}_{2} \mathrm{SO}_{4}$ & Black brown \\
\hline 04 & $\mathrm{HNO}_{3}$ & Reddish orange \\
\hline 05 & Acetone & Yellowish green \\
\hline 06 & Benzene & Olive green \\
\hline 07 & Ether & Light green \\
\hline 08 & $\mathrm{H}_{2} \mathrm{O}$ & Light yellow \\
\hline
\end{tabular}

\section{Phytochemical tests}

We carried out phytochemical tests with the powdered material of the leaf for the detection of compounds like reducing and non-reducing polysaccharides, oxalic acids, amino acids, proteins, tannins and alkaloids. The powdered material of leaf origin of Ficus carica shows the presence of reducing sugar, poly saccharides, oxalic acid, amino acid and protein while the non-reducing sugar tannins and alkaloids were not detected in the material (Table 3). Different phytochemicals have been found to possess a wide range of activities which may help in protection against different diseases. For example, alkaloids have anti-inflammatory activities; terpenoids can reduce blood sugar level.

\section{Local uses}

Locally, the fruit is used in stomach problems, bowel problems and sore throats. The leaf is used as poultice over burns and pus-filled acnes. Wood is used for fire purposes. Traditional knowledge about medicinal plants reflects the interest of local people in plant sources. Although the modern medicines are extra-ordinary in their action against diseases, medicinal plants are vital in their culinary properties [30]. Different parts of Ficus carica are used to treat diseases. Flavonoids are said to be the most active chemical constituents in all biological activities [31].

This work revealed that the plants are important source of potentially useful phytochemicals like terpenoids, proteins, 
glycosides, flavonoids, steroids, polysaccharides, etc. [32]. To conclude the present study, we have found that most of the biologically active phytochemicals are present in the ethanolic extract of Ficus carica leaves as phytochemical research carried out on $F$. carica has led to the isolation of plant metabolites.

Table 3. Phytochemical tests of the Ficus leaf extracts

\begin{tabular}{|c|c|c|c|}
\hline Test & \multicolumn{2}{|c|}{ Observation } & Result \\
\hline Benedict's test & for reducing sugars & Red color of solution & $+\mathrm{ve}$ \\
\hline Iodine test & non-reducing sugars & No change & -ve \\
\hline Tannic Acid Test & polysaccharides & Ppt formed & $+\mathrm{ve}$ \\
\hline Calcium Chloride test & Oxalic acid & White ppt & $+\mathrm{ve}$ \\
\hline Lead acetate test & Oxalic acid & White ppt & $+\mathrm{ve}$ \\
\hline Test for cysteine & Amino acid & Black ppt & $+\mathrm{ve}$ \\
\hline Biuret test & For proteins & Pink color & $+\mathrm{ve}$ \\
\hline Test for sulphur containing & \multirow{2}{*}{ For proteins } & Black Brown color of solution & $+\mathrm{ve}$ \\
\hline $\begin{array}{l}\text { *Ferric chloride } \\
\text { *Lead acetate }\end{array}$ & & No change & No change \\
*Potassium dichromate & Tests for Tannins & No change & $-\mathrm{ve}$ \\
\hline Mayer's test & Alkaloids & No ppt & -ve \\
\hline Wagner's test & Alkaloids & No ppt & $-\mathrm{ve}$ \\
\hline
\end{tabular}

\section{Antioxidant activity of leaves of Ficus carica}

Living organisms have their own defensive system which is active throughout their life. Medicinal plants are one of the rich sources of scavenging free radicles which either slow or stop oxidation [33]. The DPPH assay is widely used to check the potency of extracts to scavenge free radical and to determine the antioxidant activity in plant materials [34]. The antioxidant activity of the drug could be due to the presence of flavonoids and steroids [35]. Hazratullah [36] reported that the fruit of Ficus carica is a very good source of antioxidants and this might be due to the presence of several chemical groups like phenols flavonoids. The present study showed very good antioxidant activity of leaves extract of Ficus carica using different concentration obtained by serial dilution $(125,250, \quad 500, \quad 750$ and $1000 \mu \mathrm{g} / \mathrm{ml})$ comparing with the standard using ascorbic acid each concentration showed potent activity. Superoxide dismutase changes radicals of superoxide into hydrogen- peroxide in organisms. The leaf ethanol extract of Ficus carica possessed effective scavenging DPPH radical activity. The different concentrations gave good results in increasing order of concentration; the results are presented in (Table 4), which showed the potential antioxidant activity of Ficus carica that it has specific chemical constituents which are responsible for good result and confirms a dose dependent activity using different concentrations of the extract [37]. Evaluation of antioxidant and antimicrobial potential of different leaves crude extracts of Omani Ficus carica against food borne pathogenic bacteria [39].

\section{Antimicrobial activity of leaves of Ficus carica}

The results obtained from the present study revealed that the leaves ethanolic extract possess strong antibacterial activity against all tested microorganisms (Table 5). Ahmad et al., [2] also reported the antimicrobial activity of methanol extract of Ficus carica which showed that the plants leaf extract is a potent antimicrobial agent. Rashid et al. [37] 
reported the antimicrobial activity of latex and leaves of Ficus carica where the selected microbes were found less susceptible to extracts. Ficus carica has also been suggested as a natural oral antiseptic based on their report against oral bacteria [38]. The present study is comparable with the work of Weli et al. [39], reported the omani ficus which possess protective agents against food borne microbes. Environmental and edaphic factors might be involved for these different results of the same plant which alter the chemical composition of the medicinal plants. The difference in results may also be due to methodology adopted in various researches. Phenols and flavonoids are main constituents which are responsible for antioxidant activity. It has been found, for example that vitamin $\mathrm{C}$, carotenoid and enzymes are mostly responsible for scavenging free radicles [40, 41]. Antimicrobial activity of Ficus carica showed favourable results against selected bacterial strains which support its local uses. $K$. pneumoniae and $P$. pseudomonas aeruginosa were susceptible showing $28 \mathrm{~mm}$ zone of inhibition at $500 \mathrm{mg} / \mathrm{ml}$. Staphylococcus aureus showed $24 \mathrm{~mm}$ and 26 $\mathrm{mm}$ zone of inhibition at 200 and $500 \mathrm{mg} / \mathrm{ml}$ concentration respectively. E. coli was inhibited with $20 \mathrm{~mm}$ and $26 \mathrm{~mm}$ diameter at 200 and $500 \mathrm{mg} / \mathrm{ml}$. These differences in the zone of inhibition of the bacteria is may be due to the cell wall composition of these strains. Chemistry of the plant is responsible for any type of biological activity. Previous research also supports these results where the Ficus leave extract were found effective against pathogenic bacteria [42]. Aref et al. [43] also investigated the antimicrobial activity of latex of Ficus carica where ethyl acetate fraction produced good results by inhibiting the bacterial strains and showed that latex is also a biologically active substance.

Table 4. Antioxidant activity of the leaf extracts of Ficus carica

\begin{tabular}{|c|c|c|}
\hline Conc. of sample & Ascorbic acid & DPPH \% inhibition \\
\hline $125 \mu \mathrm{g} / \mathrm{ml}$ & $71.52 \pm 02$ & $21.42 \pm 01$ \\
\hline $250 \mu \mathrm{g} / \mathrm{ml}$ & $72.18 \pm 02$ & $29.65 \pm 03$ \\
\hline $500 \mu \mathrm{g} / \mathrm{ml}$ & $75.91 \pm 04$ & $53.15 \pm 03$ \\
\hline $750 \mu \mathrm{g} / \mathrm{ml}$ & $83.01 \pm 06$ & $57.00 \pm 01$ \\
\hline $1000 \mu \mathrm{g} / \mathrm{ml}$ & $84.11 \pm 01$ & $62.99 \pm 05$ \\
\hline
\end{tabular}

K. pneumonia was inhibited $(18 \& 28 \mathrm{~mm})$, E. coli was found $(20 \& 26 \mathrm{~mm})$ susceptible, Staphylococcus aureus was inhibited with (24 and 26mm) and Pseudomonas aeruginosa was inhibited by (22 and $28 \mathrm{~mm})$

Table 5. Antimicrobial activity of the leaf extracts of Ficus carica

\begin{tabular}{|c|c|c|c|c|c|}
\hline \multirow{2}{*}{ S. No. } & \multirow{2}{*}{ Bacterial strains } & \multicolumn{2}{|c|}{ Extract concentration } & \multirow{2}{*}{$\begin{array}{c}\text { +tive control } \\
1 \mathrm{mg} / 1 \mathrm{ml} \\
\end{array}$} & \multirow[t]{2}{*}{-tive contro } \\
\hline & & $200 \mathrm{mg} / 1 \mathrm{ml}$ & $500 \mathrm{mg} / 1 \mathrm{ml}$ & & \\
\hline 1. & K. pneumoniae & $18 \mathrm{~mm}$ & $28 \mathrm{~mm}$ & $34 \mathrm{~mm}$ & Nil \\
\hline 2. & E. coli & $20 \mathrm{~mm}$ & $26 \mathrm{~mm}$ & $29 \mathrm{~mm}$ & Nil \\
\hline 3. & Staphylococcus aureus & $24 \mathrm{~mm}$ & $26 \mathrm{~mm}$ & $30 \mathrm{~mm}$ & Nil \\
\hline 4. & Pseudomonas aeruginosa & $22 \mathrm{~mm}$ & $28 \mathrm{~mm}$ & $32 \mathrm{~mm}$ & Nil \\
\hline
\end{tabular}

\section{Conclusion}

It is concluded that Ficus carica L. has potentials metabolites to be used as an alternative to antibacterial and antimicrobial drug. The plant has many important chemicals present its crude form and that is might be the reason that it is used locally for treating various diseases in the ethnobotanical domain. This plant provides a potential source to be served as a medicine 
due to its chemical constituents based on its biological activity. More work is needed to isolate its chemical for clinical trials to be used for humanity. It is suggested that the plant has much potential in the local ethnomedical market and therefore recommend that it should be medicinally exploited for its possible treatment in diseases.

\section{Authors' contributions}

Conceived and designed the experiments: $M$ Hamayun \& HA Begum, Performed the experiments: HA Begum, Analyzed the data: M Rauf \& M Shah, Contributed materials/ analysis/ tools: M Hamayun \& H Gul, Wrote the paper: HA Begum, K Ali, W Khan \& M Schulze.

\section{References}

1. Rahman AHMM \& Khanom A (2013). Taxonomic and Ethno-Medicinal Study of Species from Moraceae (Mulberry) Family in Bangladesh Flora. Res in Plant Sci 1(3): 53-57.

2. Ahmad J, Khan I, Khan S \& Iqbal D (2013). Evaluation of Antioxidant and Antimicrobial Activity of Ficus Carica Leaves: an In-Vitro Approach. $J$ Plant Pathol Microb 4: 157.

3. Bakshi DNG, Sensarma P \& Pal DC (1999). A lexicon of medicinal plants in India. Naya Prakash, Calcutta, 424-425.

4. Luna LE (1984). The concept of plants as teachers among four Mestizo shamans of Iquitos, North-eastern Peru. $J$ of Ethnopharmacol 135-56.

5. Woodland DW (1997). Contemporary plant systematics, 2nd ed. Andrews University Press, Berrien Springs, MI, 610.

6. Shukranul M, Husain K \& Jantan I (2013). Ficus carica L. (Moraceae): Phytochemistry, Traditional Uses and Biological Activities, Evidence-Based Complementary and Alternative Medicine.
7. Jander EA \& Machado KC (2008). CA evolutionary ecology of figs and their associates: Recent progress and outstanding puzzles. Ann Rev of Nutr 39: 439-458.

8. Vinson JA (1999). Functional food properties of figs. Cereal Foods World 44(2): 82-87.

9. Gilani AH, Mehmood MH, Janbaz KH, Khan AU \& Saeed SA (2008). Ethnopharmacological studies on antispasmodic and antiplatelet activities of Ficus carica. J of Ethno-Pharmacol 119: 1-5.

10. Ross JA \& Kasum CM (2002). Dietary flavonoids: bioavailability, metabolic effects, and safety. Ann Rev of Nutr 22(1): 19-34.

11. Canal JR, Torres MD, Romero A \& Perez C (2000). A chloroform extract obtained from a decoction of Ficus carica leaves improves the cholesterolaemic status of rats with streptozotocin-induced diabetes. Acta Physiol Hung 87(1): 71-6.

12. McGovern TW (2002). The fig-Ficus carica L. Cutis 69: 339-40.

13. Kirtikar KR \& Basu BD (1996). Indian medicinal plants. International Book distributors, India, 2(3).

14. Jeong MR, Cha JD \& Lee YE (2005). Antibacterial activity of Korean Fig (Ficus carica L.) against food poisoning bacteria. Korean J of Cookery Sci 21(1): 84-93.

15. Wang $\mathrm{G}$, Wang $\mathrm{H}$, Song $\mathrm{Y}$, Jia $\mathrm{C}$, Wang $\mathrm{Z} \& \mathrm{Xu} \mathrm{H}$ (2004). Studies on anti-HSV effect of Ficus carica leaves. Zhong yao cai $=$ Zhongyaocai $=J$ of Chinese Medicinal Materials 27(10): 754-756.

16. Lee YS \& Cha JD (2010). Synergistic antibacterial activity of fig (Ficus carica) leaves extract against clinical isolates of methicillin-resistant Staphylococcus aureus. Korean $J$ of Microbiol Biotechnol 38(4): 405-13. 
17. Harzallah A, Bhouri AM, Amri Z, Soltana H \& Hammami M (2016). Phytochemical content and antioxidant activity of different fruit parts juices of three figs (Ficus carica L.) varieties grown in Tunisia. Industrial Crops and Products 83: 255-267.

18. Mahmoudi S, Khali M, Benkhaled A, Benamirouche K \& Baiti I (2016). Phenolic and flavonoid contents, antioxidant and antimicrobial activities of leaf extracts from ten Algerian Ficus carica L. varieties. Asian Pacific $J$ of Tropical Biomedicine 6(3): 239-245.

19. Krishnamoorthy A, Manjunath BN, Sastri SB \& Deshaprabhu YR (2004). The wealth of India-a Dictionary of Indian Raw materials \& Industrial products, first supplement series. Raw materias, NISCAIR, New Delhi, 1 pp 119.

20. Bolay E (1979). Figs and strangler figs. Pharm Unserver Zeit, pp 97-112.

21. Wang RW Shi L, Ai SM \& Zheng Q (2008). Trade-off between reciprocal mutualists: local resource availabilityoriented interaction in fig/fig wasp mutualism. J of Animal Ecol 77(3): 616623.

22. Wang RW \& Sun BF (2009). Seasonal change in the structure of fig-wasp community and its implication for conservation. Symbiosis 47(2): 77-83.

23. Morton F \& Morton J (1987). Fruits of warm climates, Fig. Miami, FL, 47-50.

24. Condit IJ (1928). Cytological and morphological studies in the genus Ficus L. chromosome number and morphology in seven species. Unv Calif Publ Bot 233-44.

25. Ohri D \&Khoshoo TN (1987). Nuclear DNA contents in the genus Ficus (Moraceae). Plant Systematics and Evolution 156(1-2): 1-4.

26. Evans CE, Banso A \& Samuel OA (2002). Efficacy of some nine Medicinal plants against Salmonella typhi. in vitro study. J of Ethnopharmcol 80(1): 21-24.

27. Patel RM \& Patel NJ (2011). In vitro antioxidant activity of coumarin compounds by DPPH, superoxide and nitric oxide free radical scavenging methods. J of Adv Pharm Edu \& Res 1: 52-68.

28. Achola KJ \& Munenge RW (1998). Bronchodilating and uterine activities of Ageratum conyzoides extract. Pharmaceutical Biol 36(2): 93-96.

29. Perez F, Endimiani A, Hujer KM \& Bonomo RA (2007). The continuing challenge of ESBLs. Current Opinion in Pharmacol 7(5): 459-469.

30. Shinwari ZK, Malik S, Karim AM, Faisal R \& Qaiser M U (2015). Biological activities of commonly used medicinal plants from Ghazi Brotha, Attock district. Pak J of Bot 47(1): 11320.

31. Bouyahya A, Bensaid M, Bakri Y \& Dakka N (2016). Phytochemistry and Ethnopharmacology of Ficus carica. Int J Biochem Res Rev 14: 1-2.

32. Doughari JH (2012). Phytochemicals: Extraction methods, basic structures and mode of action as potential chemotherapeutic agents. In Phytochemicals-A global perspective of their role in nutrition and health. In Tech open.

33. Devasagayam TPA, Tilak JC, Boloor KK, Sane KS, Ghaskadbi SS \& Lele RD (2004). Free radicals and antioxidants in human health: current status and future prospects. Japi 52(794804): 4.

34. Bidchol AM, Wilfred A, Abhijna P \& Harish R (2011). Free radical scavenging activity of aqueous and ethanolic extract of Brassica oleracea L. var. italica. Food and Bioprocess Technol 4(7): 11371143.

35. Ali B, Mujeeb M, Aeri V, Mir S R, Faiyazuddin M \& Shakeel F (2012). 
Anti-inflammatory and antioxidant activity of Ficus carica Linn. leaves. Natural Product Res 26(5): 460465.

36. Harzatullah A, Bhouri AM, Amri Z, Soltana H \& Hammami M (2016). Phytochemical content and antioxidant activity of different fruit parts juices of three figs (Ficus carica L.) varieties grown in Tunisia. Industrial Crops and Products 83: 255-267.

37. Rashid KI, Mahdi NM, Alwan MA \& Khalid LB (2014). Antimicrobial activity of fig (Ficus carica Linn.) leaf extract as compared with latex extract against selected bacteria and fungi. $J$ of Uni of Babylon 22(5): 1620-1626.

38. Jeong MR, Kim H Y \& Cha JD (2009). Antimicrobial activity of methanol extract from Ficus carica leaves against oral bacteria. $J$ of Bacteriol and Virol 39(2): 97-102.

39. Weli AM, Al-Blushi AAM \& Hossain MA (2015). Evaluation of antioxidant and antimicrobial potential of different leaves crude extracts of Omani Ficus carica against food borne pathogenic bacteria. Asian Pacific $J$ of Trop Dis 5(1): 13-16.
40. Kamal Z, Farhat Uallh, Ayaz M, Sadiq A, Ahmad S, Zeb A, Hussain A \& Imran $M$ (2015). Anticholinesterase and antioxidant investigation of crude extracts, subsequent fractions, saponin and flavonoids of Atriplex laciniata: potential effectiveness in Alzheimer's and other neurological disorders. Biol Res 48(1): 21.

41. Tajdar M, Nisar U, Ali K, Kamran A, Inayat U R, Waqar K, Murad A, Shams U Z, Nousheen N, Farma, U, Zahir A \& Mohammad N (2017). In-vitro antioxidant and anti-microbial potential of the pollen extracts of Pinus roxburghii Sarg. $J$ of Biodiver and Environ Sci 11(3): 46-55.

42. Al-Yousuf, HHH (2012). Antibacterial activity of Ficus carica L. extract against six bacterial strains. Inter $J$ of Drug Devel and Res 4(4).

43. Aref HL, Salah KB, Chaumont JP, Fekih A, Aouni M \& Said K (2010). In vitro antimicrobial activity of four Ficus carica latex fractions against resistant human pathogens (antimicrobial activity of Ficus carica latex). Pak $J$ Pharm Sci 23(1): 53-58. 